\title{
Characterization of ruminal bacteria in grazing Nellore steers
}

\author{
Caracterización de bacterias ruminales en novillos Nelore en pastoreo \\ Caraterização bacteriana ruminal em novilhos Nelore em pastejo
}

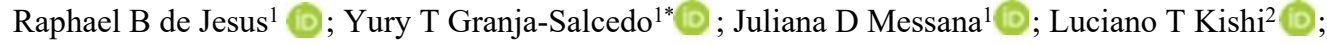 \\ Eliana G M Lemos ${ }^{3}$ ( $)$; Jackson Antonio M de Souza ${ }^{3}$; ; Telma T Berchielli ${ }^{1}$.
}

\begin{abstract}
${ }^{1}$ Departamento de Zootecnia, Faculdade de Ciências Agrarias e Veterinárias (FCAV), Universidade Estadual Paulista (UNESP), Câmpus Jaboticabal, Jaboticabal SP, Brazil.

${ }^{2}$ Departamento de Tecnologia, Faculdade de Ciências Agrarias e Veterinárias (FCAV), Universidade Estadual Paulista (UNESP), Câmpus Jaboticabal, Jaboticabal, SP, Brazil.

${ }^{3}$ Departamento de Biologia, Faculdade de Ciências Agrarias e Veterinárias (FCAV), Universidade Estadual Paulista (UNESP), Câmpus Jaboticabal, Jaboticabal, SP, Brazil.
\end{abstract}

Received: November 7, 2017; accepted: March 5, 2019

To cite this article:

De Jesus RB, Granja-Salcedo YT, Messana JD, Kishi LT, Lemos EGM, De Souza JAM, Barchielli TT. Characterization of ruminal bacteria in grazing Nellore steers. Rev Colomb Cienc Pecu 2019; 32(4): 248-260.

DOI: https://doi.org/10.17533/udea.rccp.v32n4a01

(cc) BY-NC-SA This work is licensed under a Creative Commons Attribution-NonCommercial-ShareAlike 4.0 International License. 


\section{Abstract}

Background: Rumen microorganisms have developed a series of complex interactions, representing one of the best examples of symbiosis between microorganisms in nature. Conventional taxonomic methods based on culture techniques are being replaced by molecular techniques that are faster and more accurate. Objective: To characterize rumen bacterial diversity of Nellore steers grazing on tropical pastures by sequencing the 16S rRNA gene using Illumina sequencing. Methods: Three rumen-cannulated Nellore steers were used. The liquid and solid fractions of the rumen contents were processed to extract metagenomic DNA, and the V1 and V2 hypervariable regions of the 16S rRNA gene were sequenced using Illumina sequencing. Results: A total of 11,407,000 reads of adequate quality were generated, and 812 operational taxonomic units (OTUs) were found at the species level. Twenty-seven phyla were identified, and the predominant phyla were Firmicutes (23\%), Bacteroidetes (14\%), Proteobacteria (10\%), Spirochaetes (9\%), Fibrobacteres (7\%), Tenericutes (5\%), and Actinobacteria $(2 \%)$, which represented $70 \%$ of the total phyla identified in the rumen content. Conclusion: Rumen environment in grazing Nellore steers showed high bacterial diversity, with Firmicutes, Bacteroidetes, Proteobacteria, Spirochaetes, and Fibrobacteres as the predominant phyla.

Keywords: bacterial diversity; Cynodon spp; Firmicutes; Nellore; new generation sequencing; steers; ruminant; ruminal bacteria; rumen microorganisms; Zebu.

\section{Resumen}

Antecedentes: Los microorganismos ruminales han desarrollado una serie de interacciones complejas que representan uno de los mejores ejemplos de simbiosis entre microorganismos en la naturaleza. Los métodos taxonómicos tradicionales basados en técnicas de cultivo están siendo reemplazados por técnicas moleculares debido a su mayor velocidad y precisión. Objetivo: Caracterizar la diversidad bacteriana ruminal de novillos Nelore mantenidos en pasturas tropicales mediante la secuenciación del gen 16S RNA utilizando la plataforma de secuenciación Illumina. Métodos: Se utilizaron tres novillos Nelore fistulados en el rumen. Las fracciones líquida y sólida del contenido ruminal fueron procesadas para la extracción del DNA meta genómico y las regiones hipervariables V1 y V2 del gen 16S rRNA fueron secuenciadas usando la plataforma Illumina. Resultados: En total, se generaron 11.407.000 lecturas de calidad adecuada, y en el nivel de especie se encontraron 812 unidades taxonómicas operacionales (OTUs). Se identificaron veintisiete filos, predominantemente Firmicutes (23\%), Bacteroidetes (14\%), Proteobacteria (10\%), Spirochaetes (9\%), Fibrobacteres (7\%), Tenericutes (5\%) y Actinobacteria $(2 \%)$, los cuales representaron el $70 \%$ de los filos identificados en el contenido ruminal. Conclusión: El ambiente ruminal de novillos Nelore en pastoreo presenta una alta diversidad de bacterias, con dominancia de los filos Firmicutes, Bacteroidetes, Proteobacteria, Spirochaetes y Fibrobacteres.

Palabras clave: bacterias ruminales; Cynodon spp; diversidad bacteriana; Firmicutes; Nelore; novillos; microorganismos ruminales; rumiante; secuenciación genética; secuenciación de última generación; Zebú.

\section{Resumo}

Antecedentes: Os microrganismos ruminais têm desenvolvido uma serie de complexas interações que representam um dos melhores exemplos de simbiose entre microrganismos na natureza. Os métodos taxonômicos tradicionais baseados em métodos de cultura vêm sendo substituídos por técnicas moleculares que apresentam maior velocidade a acurácia. Objetivo: Caracterizar a diversidade bacteriana ruminal em novilhos Nelore mantidos em pastagens tropicais mediante o sequenciamento do gene 16S rRNA utilizando a plataforma de sequenciamento Illumina. Métodos: Foram utilizados três novilhos Nelore fistulados no rúmen. A fração liquida e solida do conteúdo ruminal foram processadas para extrair o DNA metagenômico, e as regiões hipervariáveis V1 e V2 do gene 16S rRNA foram sequenciadas na plataforma Illumina. Resultados: No total foram geradas 11.407.000 leituras de qualidade adequada, e 812 unidades taxonomicas operacionais (OTUs) foram identificadas no nível de espécie. Foram identificados 27 filos, e houve predominância de Firmicutes (23\%), Bacteroidetes (14\%), Proteobacteria (10\%), Spirochaetes (9\%), Fibrobacteres (7\%), Tenericutes (5\%) e Actinobacteria (2\%), os quais representaram $70 \%$ dos filos identificados a partir do rúmen bovino. Conclusão: $\mathrm{O}$ ambiente ruminal em novilhos Nelore em pastejo apresentou alta diversidade bacteriana, com Firmicutes, Bacteroidetes, Proteobacteria, Spirochaetes e Fibrobacteres como filos predominantes.

Palavras-chave: bacteria ruminal; Cynodon spp; diversidade bacteriana; Firmicutes; Nelore; novilhos; microrganismos ruminais; ruminante; sequenciamento genético; sequenciamento de nova geração; Zebu. 


\section{Introduction}

Beef cattle in Brazil are primarily grazed on tropical grass pastures. Nellore (Bovinus indicus) breed -which is the most exported beef in the world- comprises the greatest number of bovine herds in this country, (MAPA, 2016). Tifton 85 hay is a commonly used forage for ruminants owing to its high dry matter yield, although its quality is low due to high fiber and low protein content (Hill et al., 1993).

Determining the mechanics of ruminant nutrition poses the challenge of understanding the composition of rumen microbiota, which is too complex and not fully understood. More than 200 bacterial species have been identified from rumen contents using classical isolation. Only $10-20 \%$ of the rumen microbial population has been identified using molecular methods (Sylvester et al., 2004). Given the high diversity of uncultured microorganisms, it is essential to adopt new methods -such as the new genebased technologies- to overcome the limitations of culture-based techniques to provide accurate and rapid assessment of microbial populations (Granja-Salcedo et al., 2017) for further investigating rumen bacterial diversity.

Seasonal changes reduce the quality and quantity of forage in tropical grass pastures (Reis et al., 2009), thereby possibly limiting feed intake and reducing energy efficiency, hence, resulting in lesser microbial protein synthesis (Yang et al., 2006) and decreased animal performance. Studying rumen microbial diversity is essential to understand the ecological relationships in that environment and for future development of applied technologies to improve ruminant performance. Thus, the main objective of this study was to characterize rumen bacterial diversity of Nellore steers grazing on tropical grass and supplemented with concentrate by sequencing the 16S rRNA gene using Illumina sequencing.

\section{Materials and methods}

\section{Ethical considerations}

All stages of the experiment were performed in accordance with the ethical principles for animal experimentation adopted by the Brazilian College of Animal Experimentation, and were approved by the Ethics Committee on Animal Use at Faculdade de Ciências Agrarias e Veterinárias (FCAV) of Universidade Estadual Paulista, Brazil; Protocol 017621/11.

\section{Animals and diet}

Ruminal cannulation was conducted six months prior to the experiment under xylazine sedation and local anesthesia with lidocaine hydrochloride; all efforts were made to minimize suffering.

To allow identifying a high number of microorganisms, three rumen-cannulated Nellore steers, aged approximately 24 months with an average weight of $350 \pm 11 \mathrm{~kg}$, were used. The feed, provided once per day, was composed of a mixture of ground Tifton 85 hay (70\%; Cynodon spp) and a concentrate $(30 \%)$ consisting of soybean meal $(13.1 \%)$, corn meal (15.7\%), urea, and ammonium sulfate $(1.2 \%)$. Average daily dry matter intake was approximately $1.7 \%$ of the live weight of the animal, and water was provided ad libitum. The period of adaptation to the diet was 31 days, and rumen contents were sampled $1 \mathrm{~h}$ before feeding the animals.

\section{Rumen sampling and metagenomic DNA extraction}

From each animal, two rumen content samples, liquid and solid fraction, were collected through the cannula. Rumen contents were filtered through sterile gauze, and 500 $\mathrm{ml}$ of the resulting filtrate (liquid fraction) was centrifuged at $27,000 \times g$ for $30 \mathrm{~min}$ at 4 ${ }^{\circ} \mathrm{C}$, and the supernatant was discarded. The pellet was resuspended in $40 \mathrm{ml} 0.85 \% \mathrm{NaCl}$ 
and centrifuged under the same conditions as described above; the supernatant was again discarded. Finally, the pellet was resuspended in $40 \mathrm{ml} 0.85 \% \mathrm{NaCl}$.

The partially digested plant material separated by filtering was considered as the solid fraction of the rumen contents. For separating microorganisms attached to the solid fraction, $30 \mathrm{ml} 0.85 \% \mathrm{NaCl}$ solution containing $0.2 \%$ Tween $^{\circledR} 20$ (Sigma, St Louis, MO, USA) was added to $10 \mathrm{~g}$ of the solid fraction of the rumen contents. The sample was homogenized vigorously for $1 \mathrm{~min}$ and centrifuged for 10 $\min$ at $1,000 \times g$ at $4{ }^{\circ} \mathrm{C}$. The supernatant was transferred to a new test tube stored on ice. The pellet was resuspended in $30 \mathrm{ml} 0.85 \% \mathrm{NaCl}$ solution containing $0.2 \%$ Tween ${ }^{\circledR} 20$ (Sigma, St Louis, MO, USA) and centrifuged as described above. The supernatant thus obtained was transferred to a tube stored on ice. The pellet was resuspended in the solution described above along with glass beads, vigorously homogenized, and centrifuged under the abovementioned conditions. The supernatant was recovered and stored along with the previously stored supernatants. The tubes stored on ice containing the supernatants from the previous three steps were centrifuged at $27,000 \times g$ for $30 \mathrm{~min}$ at $4{ }^{\circ} \mathrm{C}$. The supernatant was discarded, and the resulting pellet was resuspended in $3 \mathrm{ml}$ $0.85 \% \mathrm{NaCl}$. Prior processing of the harvested material was performed to extract DNA from both samples.

Total DNA was extracted using $250 \mathrm{mg}$ of both fractions using a FastDNA ${ }^{\circledR}$ SPIN Kit for Soil (MP Bio, Biomedicals, Illkirch, France; GranjaSalcedo et al., 2017). Integrity and quantity of DNA were verified on $0.8 \%$ agarose gel stained with ethidium bromide $(5 \mathrm{mg} / \mathrm{ml})$. The size of the bands was estimated by comparison with a 1 $\mathrm{kb}$ plus DNA ladder (Invitrogen, Waltham, MA, USA). Additionally, the DNA was assessed for quality and quantity using a spectrophotometer (NanoDrop 1000, Thermo Fisher Scientific, Waltham, MA, USA).

16S rRNA gene fragments from both the samples were amplified by PCR using the primers Y1 (5'-TGG CTC AGAACG AAC GCT GGC GGC-3') and Y2 (5'-CCC ACT GCT GCC TCC CGT AGG AGT-3'; Young et al., 1991). PCR was performed using $20 \mathrm{ng}$ of total DNA in a reaction mixture containing $1.25 \mathrm{mM} \mathrm{MgCl}_{2}$, $200 \mu \mathrm{M}$ dNTP, $1.0 \mathrm{U}$ Taq DNA polymerase (Invitrogen, Waltham, MA, USA), PCR reaction buffer $(1 \times), 10$ pmol of each primer, and $\mathrm{ddH}_{2} \mathrm{O}$ to a final volume of $20 \mu \mathrm{l}$. PCR was performed under the following conditions: $95{ }^{\circ} \mathrm{C}$ for 2 min; 35 cycles of denaturation at $95^{\circ} \mathrm{C}$ for $45 \mathrm{~s}$, annealing at $65^{\circ} \mathrm{C}$ for $45 \mathrm{~s}$, and extension at 72 ${ }^{\circ} \mathrm{C}$ for $1 \mathrm{~min}$; and final extension at $72{ }^{\circ} \mathrm{C}$ for 5 min. After fragment amplification, both samples were mixed equimolarly.

\section{Library construction and sequencing}

A library of the 16S rDNA fragments from the rumen contents was constructed according to the protocol for the Truseq ${ }^{\mathrm{TM}}$ DNA Sample Preparation Kit v2 (Illumina, Hayward, CA, USA) following the manufacturer's instructions. Sequencing was performed on the HiscanSQ (Illumina, Hayward, CA, USA) platform using the Paired-End Cluster Generation Kit v3 and TruSeq SBS kit v3 (200 cycles) (Illumina, Hayward, CA, USA). After sequencing, the CASAVA sequencing datasets software, version 1.8.2 (Illumina, Hayward, CA, USA) was used to separate the generated barcodes and to convert the generated BCL file to a FASTQ file.

\section{Data analysis}

Output files from the CASAVA software (Illumina, Hayward, CA, USA) were used as input files for the analyses performed in the MOTHUR and MG-RAST programs. Sequence trimming was performed by selecting sequences above $200 \mathrm{bp}$ with an average quality score of $>20$, based on Phred quality, and duplicate reads were removed using the Prinseq program (Schmieder etal., 2011). Chaol and ACErichness estimators and Shannon-Weaver and Simpson diversity indices were obtained from MOTHUR using SILVA (Chao, 1987; Pruesse et al., 2007) database as the reference for phylogenetic 
classification of the reads. MG-RAST was used to perform rarefaction analysis by plotting the number of operational taxonomic units (OTUs) clustered at 95 and $97 \%$ similarity relative to the number of reads, and the Usearch algorithm was used to cluster the read OTUs with a $97 \%$ cutoff and to assign the taxonomy using the Ribosomal Database Project II (RDPII), version 10 (Cole et al., 2014).

\section{Results}

A total of 11,407,000 sequences of up to 200 base pairs (bp) were obtained from the amplified fragments. Rarefaction analysis was performed by plotting the number of OTUs clustered at 95 and $97 \%$ similarity relative to the number of reads for the taxonomic levels of genus and species, respectively (Figure 1). Shannon and Simpson diversity, and ACE and Chaol richness parameters are shown in Table 1.

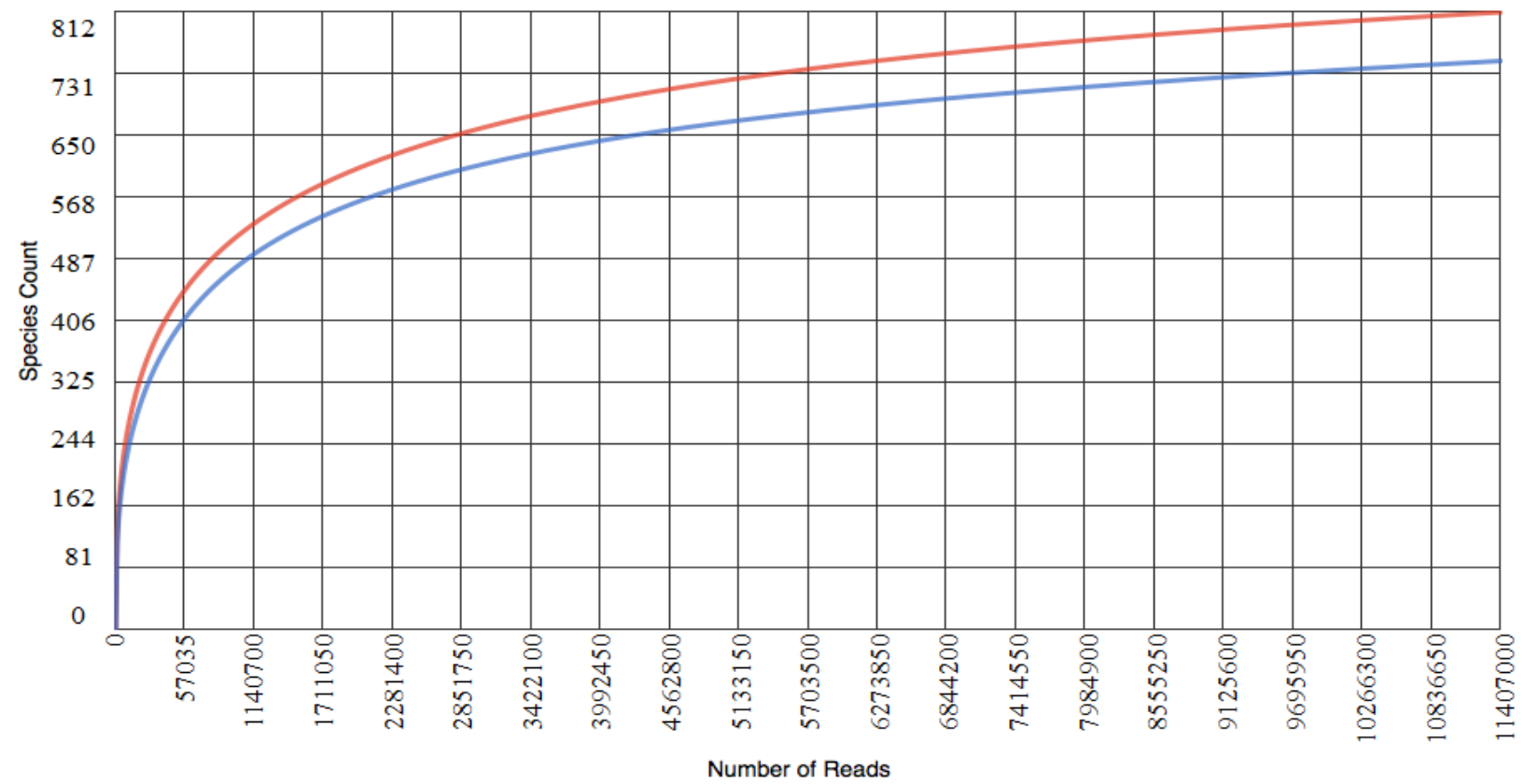

Figure 1. Rarefaction curve indicating the number of operational taxonomic units (OTUs) with evolutionary distances of $3 \%$ (red line), and 5\% (blue line) based on the reads obtained by sequencing the 16S rRNA gene fragment.

Table 1. Indices of richness (ACE and Chao1) and diversity (Shannon and Simpson) for bovine rumen contents with evolutionary distances of 3 and $5 \%$.

\begin{tabular}{lcccc}
\hline \multicolumn{1}{c}{ Similarity } & ACE & Chao1 & Shannon & Simpson \\
\hline Unique & $16,648,025.99$ & $5,106,763.32$ & 6.715 & 0.027 \\
$97 \%$ & $16,642,538.39$ & $5,106,630.82$ & 6.711 & 0.027 \\
$95 \%$ & $10,574,731.56$ & $3,658,795.70$ & 6.328 & 0.029
\end{tabular}


Twenty-seven phyla were identified in the analyzed rumen microbiome, and $29 \%$ of the sequences were determined to be unclassifiable at the phylum level. Among the classified phyla, Firmicutes $(23 \%)$, Bacteroidetes $(14 \%)$, Proteobacteria (10\%), Spirochaetes $(9 \%)$, Fibrobacteres $(7 \%)$, Tenericutes $(5 \%)$, and Actinobacteria (2\%) -which represented $70 \%$ of the total phyla identified from the bovine rumen- were predominant. The other 20 phyla observed [Synergistetes $(0.9 \%)$; Lentisphaerae $(0.2 \%)$; Planctomycetes $(0.2 \%)$; Chlorobi $(0.1 \%)$; Fusobacterium $(0.02 \%)$; Acidobacteria $(0.02 \%)$; Cyanobacteria $(0.01 \%)$; Chloroflexi $(0.01 \%)$; Nitrospirae $(0.009 \%)$; Verrucomicrobia $(0.007 \%)$; Deferribacteres $(0.004 \%)$;
Gemmatimonadetes $(0.003 \%)$; Elusimicrobia $(0.002 \%)$, Thermodesulfobacteria $(0.002 \%)$, Poribacteria $(0.002 \%)$, and Thermotogae $(0.00007 \%)$; Aquificae $(0.00007 \%)$; Chlamydiae $(0.00003 \%)$; Chrysiogenetes $(0.00003 \%)$; and Deinococcus-Thermus $(0.00001 \%)]$ represented a smaller percentage.

Taxonomic classifications at the class level for the seven major bacterial phyla found in the bovine rumen contents are presented in Figure 2. Four classes were identified for each of the phyla Firmicutes and Bacteroidetes. Six classes were identified for the phylum Proteobacteria. Only one class was identified for each of the phyla, Spirochaetes, Fibrobacteres, Tenericutes, and Actinobacteria.

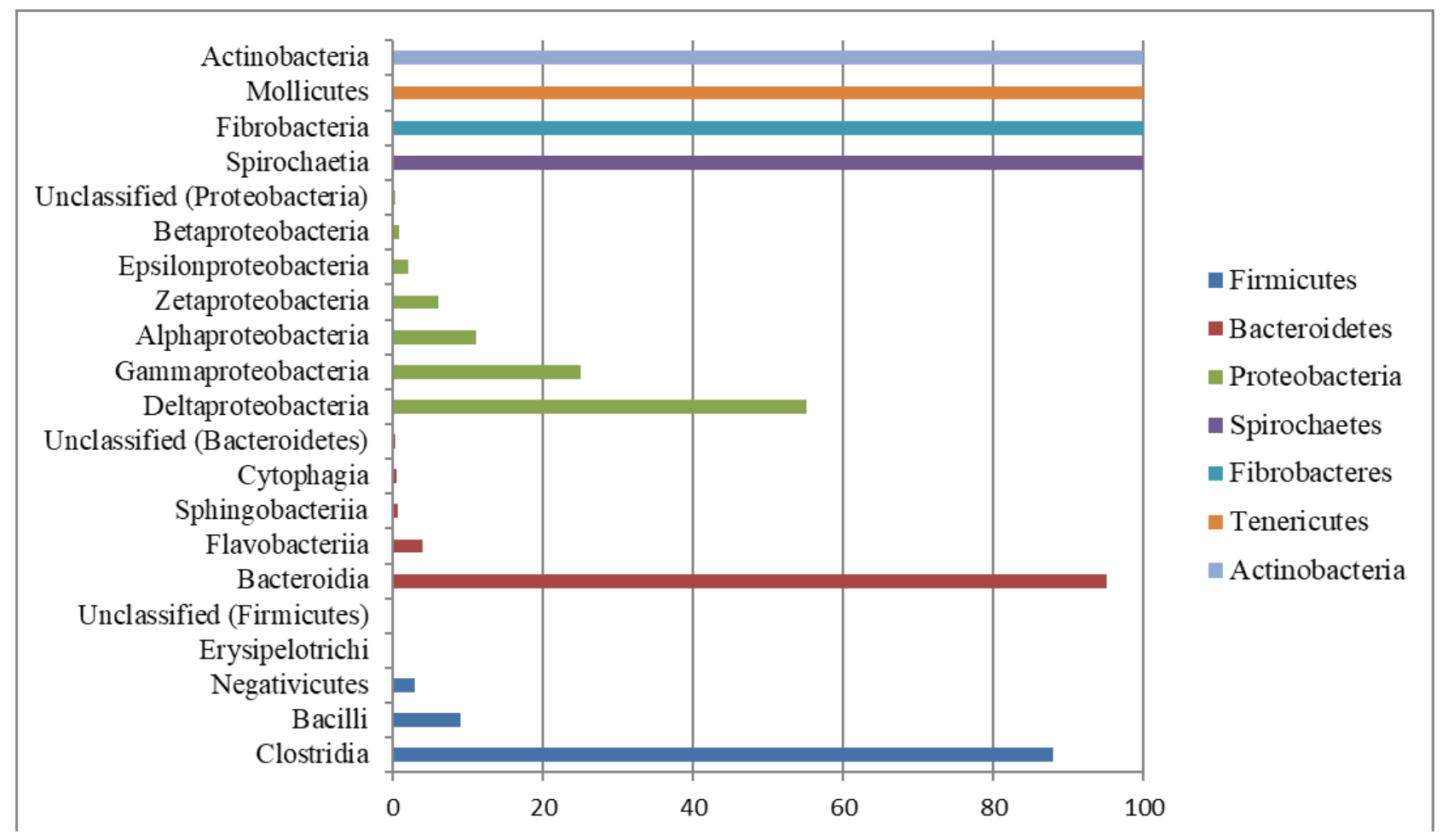

Figure 2. Taxonomic relationships at the class level for reads generated from sequences of the 16S rRNA gene fragment from bovine rumen contents through the Illumina platform.

Taxonomic classifications at the genus level for the five major bacterial phyla present in bovine rumen contents are summarized in Figure 3. Four main genera were identified for the phylum Firmicutes. Two main genera were identified for the phyla Bacteroidetes and Proteobacteria. One major genus was identified for the phylum Spirochaetes, and only one genus was identified for the phylum Fibrobacteres. 


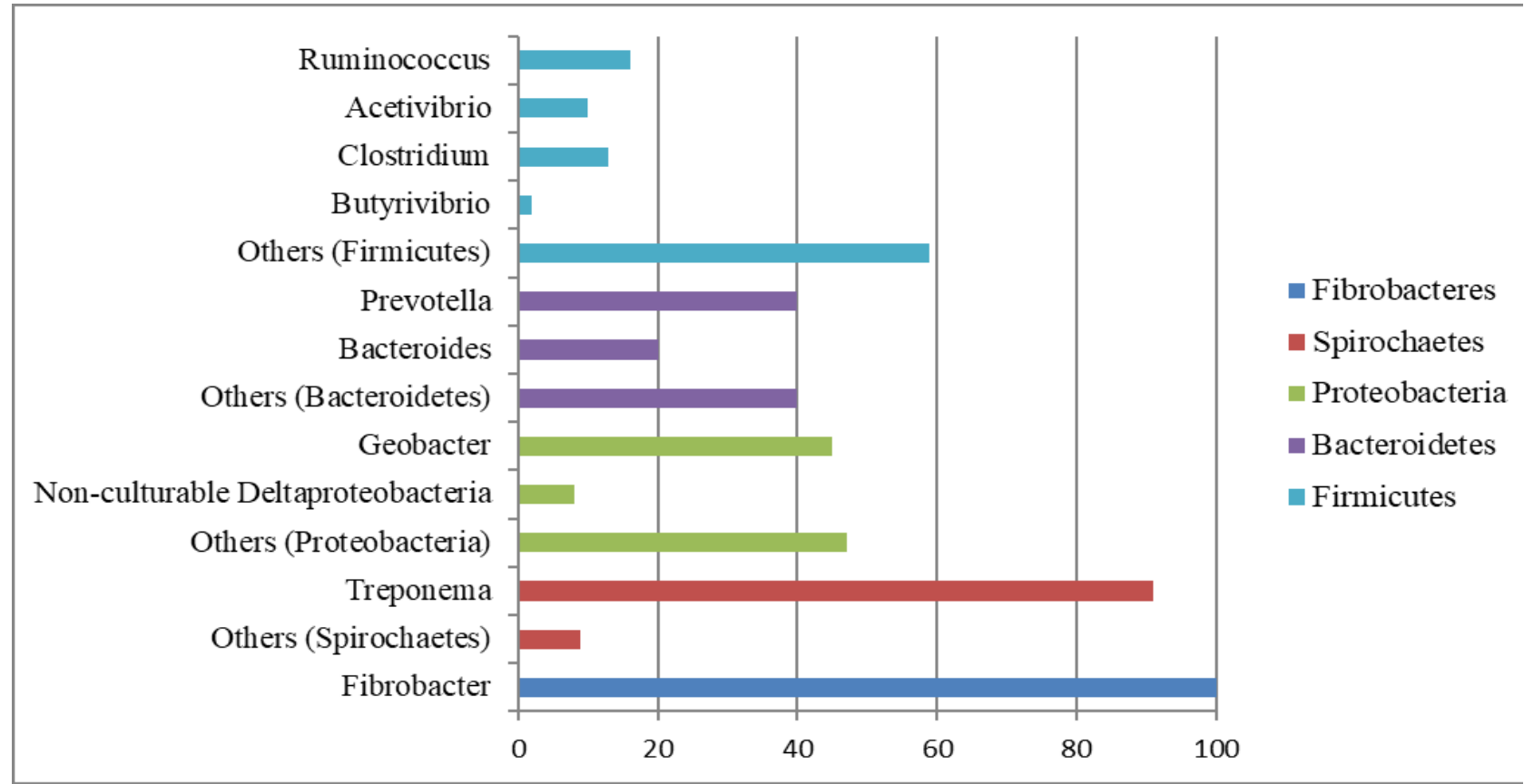

Figure 3. Taxonomic relationships at the genus level for reads generated from sequences of 16S rRNA gene fragment from bovine rumen contents through the Illumina platform.

\section{Discussion}

In this study, we characterized the rumen bacterial diversity of Nellore steers grazing in tropical grass pastures supplemented with concentrate. The high-throughput sequencing approach proved to be a powerful tool to reveal the bacterial diversity of sieved rumen contents and contributed toward a better understanding of the in vivo ecological relationships and toward developing applied technologies for improving ruminant performance in the future.

Rarefaction analysis is an important parameter for estimating the species richness achieved in the analysis and further indicates whether the coverage obtained is sufficient to reveal the full diversity of the sampled community. As observed in Figure 1, 812 distinct OTUs were identified in the rumen contents assessed in the analysis at 97\% similarity and 752 distinct OTUs were identified for the analysis at 95\% similarity, considering the conditions applied in MOTHUR analysis. The shape of the rarefaction plot revealed that the $11,407,000$ sequences almost accurately represented the

overall complexity of the assessed microbial community, which almost reached the plateau of the curve as confirmed by the ACE richness estimator, wherein the sequences were grouped as rare and abundant according to their frequency of observation, and by the Chaol richness estimator, from which the number of missing species can be estimated. The Shannon-Weaver index is a general diversity index that is sensitive to both the richness and relative abundance of the species; the index increases with diversity (Magurran, 2004). The Simpson index is a value between 0 and 1 , and values closer to 0 indicate higher observed diversity (Magurran, 2004). Indices such Ace, Chao1, Shannon and Simpson support the high diversity of the rumen environment (Table 1). Richness estimators and diversity indices showed that rumen bacterial microbiota is relatively rich and diverse and description of the community from the number of reads obtained was adequate. The Ace, Chao1, and Shannon values were higher than those observed by Granja-Salcedo et al. (2017) in one Nellore steer grazing on similar forage. These 
findings effectively demonstrate the power of metagenomic techniques combined with Illumina sequencing, which enables access to much of the microbial community not revealed by traditional microbiology and molecular biology techniques.

The taxonomic resolution of the technique used, 16S rRNA gene sequencing, conclusively classified the groups up to family and genus levels. Because of the different sequencing options for hypervariable regions of the marker used, reliable classification at the species level requires further exploration of the data (Vandamme, 1996). Clear recommendations have not yet been established for determining genus or higher taxonomic levels, particularly when the genetic similarity between representative strains of a consensus group and the genetic similarity observed with the database is less than $97 \%$. In such cases, deciding whether a particular group belongs to a novel or already existing genus is subjective and guided by stability evaluation of the phylogenetic position of the group in question (Gillis, 2001).

Sequencing on the Illumina platform allowed for the identification of 27 distinct phyla in the rumen contents, a higher number than that reported by Granja-Salcedo et al. (2017), Kim et al. (2011), and Li et al. (2012) who found 17, 21, and 19 phyla in bovine rumen, respectively, but using other sequencing techniques. Henderson et al. (2015) demonstrated that rumen microbial community can be influenced by diet and host, thus the differences in identified phyla in our study may be due to the sequencing technology used and the different animal breed, basal diet and environmental conditions.

Our bacterial diversity results showed high abundance of Firmicutes, followed by the Bacteroidetes phylum. This finding is consistent with a previous study on rumen microbiota of Zebu cattle in grazing systems (Oliveira et al., 2013; McCann et al., 2014; Granja-Salcedo et al., 2017) and confirmed that Firmicutes and Bacteroidetes play important roles in the metabolism of ruminants fed tropical forages.
These previous data are conclusive and congruent with our data and demonstrate the potential of metagenomics for scrutinizing new microbial taxa and for future interventions to obtain new biotechnological resources potentially used in animal nutrition. Twenty other phyla were identified with low percentages. Some of these phyla have not yet been described in the rumen environment and their function may be as important as those of the phyla with the highest percentages.

Among the most abundant phyla found, Firmicutes was the most dominant with $23 \%$ of the total analyzed reads. The Firmicutes phyla with higher expression in this phylum included Ruminococcus, which was first described in 1948 and isolated from bovine rumen contents (Sijpestejin, 1949). The type species for this genus was the bacterium Ruminococcus flavefaciens, which together with $R$. albus, is a major degrader of structural carbohydrates (Flint et al., 2012). In addition, an important expression of Acetivibrio genera was observed, which is a cellulase-producing bacteria (Ling et al., 2014). These results are suggestive that the phylum Firmicutes have an important function in rumen fibrinolytic activity of grazing cattle.

The genus Clostridium in the phylum Firmicutes includes two major species: $C$. proteoclasticum, which primarily performs proteolytic activities (Attwood et al., 1996), and $C$. lundense, which is related to lipolytic activity (Cirne et al., 2006). Butyrivibrio is another important genus in the phylum Firmicutes and was first described by Bryant and Small et al. (1956). The type species B. fibrisolvens was isolated from the bovine rumen. These genera are typically associated with the fermentation of soluble carbohydrates and play a major role in the degradation of starch granules (Mcallister, 1990). Additionally, B. fibrisolvens plays a significant role in the proteolytic functions of the rumen (Attwood and Reilly, 1995).

The second most abundant phylum was Bacteroidetes, representing $14 \%$ of the total sequences analyzed. The two genera with the highest expression in this phylum were 
Bacteroides and Prevotella. Bacteroides featured two main species in the bovine rumen, $B$. ruminicola and $B$. amylophilus. The genus Prevotella is one of the most numerous ruminal bacteria, representing approximately $60 \%$ of the isolates (Van Gylswyk et al., 1990). The species with the highest prevalence included $P$. bryantii, $P$. ruminicola, and $P$. brevis, with their main functions in the rumen being degradation and utilization of starch (Cotta, 1992) and degradation of polysaccharides, such as xylan and pectin, from the plant cell wall; however, they do not degrade cellulose. These bacteria are also strongly related to protein degradation and peptide fermentation (Pittman and Bryant et al., 1964; Russel et al., 1983; Wallace et al., 1993).

Geobacter species are obligate anaerobes that can completely oxidize organic compounds such as acetate and other short-chain fatty acids to carbon dioxide (Lovley, 2000). In addition, some Geobacter species can reduce nitrate and fumarate (Coppi et al., 2001). This genus has been identified in cattle rumen samples (Henderson et al., 2015; Granja-Salcedo et al., 2017); however, no assertion about the importance or function of this genus in the ruminal microbiota was proposed. In contrast, Geobacter has been studied principally in soils, where they are dominant metal-reducing microorganisms in a variety of anaerobic subsurface environments and are involved in the bioremediation of both organic and metal contaminants (Coppi et al., 2001).

The phylum Proteobacteria, the third most frequently occurring phylum identified, represented $10 \%$ of the total reads. Similar results were found by Kim et al. (2011). They gathered data from the Ribosomal Database Project (RDP), finding that the third most abundant phylum was Proteobacteria, which is similar to our study, with approximately $7 \%$ of the sequences.

Spirochaetes was the fourth most abundant phylum with $9 \%$ of all the sequences. Our results agree with those of Pandya et al. (2010), who found $9.52 \%$ of the sequences for the phylum Spirochaetes. The results, however, disagree with those by Tajima et al. (1999) and Wu et al. (2012), who reported 2.4 and 1\% for the same phylum, respectively. Treponema was the largest group observed at the genus level within the phylum Spirochaetes. In the rumen, the most important species of this genus were $T$. bryantii and $T$. saccharophilum, which are engaged primarily in the fermentation of soluble carbohydrates (Stanton and Canale-Parola, 1980).

Another phylum with low abundance, but with a very important functional role was Fibrobacteres, including Fibrobacter succinogenes, which is a major cellulolytic rumen bacterium (Kobayashi et al., 2008; Flint et al., 2012). Briesacher et al. (1992) showed that approximately $5-6 \%$ of the total $16 \mathrm{~S}$ rRNA in bovine rumen contents is from $F$. succinogenes. Several experimental studies under similar conditions in Nellore cattle grazing quantified $F$. succinogenes by real time PCR showed that, even with low abundance in the rumen microbiota $(<5 \%)$, these bacteria are important for forage degradation (San Vito et al., 2016; Carvalho et al., 2017; Neto et al., 2017).

Although the animal and the rumen microbial community benefit from synergistic and mutualistic relationships among microorganisms (archaea, bacteria, protozoa and fungi), there is a delicate balance between the individual microbial populations, since each contributes metabolically to the conversion of substrates into fermentation products, and population equilibrium can be adjusted by subtle variations in the diet (Murray, 1997).

The next generation of sequencing techniques presents potential for future biotechnological applications associated with improving and optimizing animal diet and nutrition (Deng et al., 2008). As shown in the present study, there is great potential for developing more productive ruminant systems based on a thorough understanding of the rumen microbiota. Molecular methods have allowed for the generation of initial knowledge about the 
rumen bacterial diversity.

The present work identified 27 phyla in the rumen contents of Nellore steers in tropical grass pastures, with Firmicutes, Bacteroidetes, Proteobacteria, Spirochaetes, and Fibrobacteres being the predominant phyla. Many of these microorganisms are not easily isolated by traditional culture techniques (Amann et al., 1995). New ideas can guide studies to understand their synergistic and antagonistic roles and provide possible means of separating biological resources in the form of bacterial isolates, enzymes, or genes. Future studies are needed to elucidate the role of bacteria such Geobacter and Acetivibrio in the rumen microbiome and to better characterize more than twenty bacterial phyla identified in this study which, although less abundant, could play important roles in forage degradation.

\section{Declarations}

\section{Acknowledgments}

This work was supported by the National Council of Technological and Scientific Development (CNPq - 475844/2012-2), by the Postgraduate Program in Animal Science of UNESP, FCAV, Jaboticabal and the São Paulo Research Foundation (FAPESP - 2013/ 23851-6 and 2015/17966-0).

\section{Funding}

São Paulo Research Foundation (FAPESP) and Faculdade de Ciências Agrarias e Veterinárias (FCAV), Universidade Estadual Paulista (UNESP)

\section{Conflicts of interest}

The authors declare they have no conflicts of interest with regard to the work presented in this report

\section{Author contributions}

Conceived and designed the experiment:
RBJ, LTK, EGML and JAMS. Performed the experiment: RBJ and YTGS. Laboratorial analysis: RBJ, and YTGS. Bioinformatical analysis: LTK. Wrote the manuscript: RBJ, JDMS andYTGS. Final review: JDM, YTGS, JAMS and TB.

\section{References}

Amann RI, Ludwig W, Schleifer KH. Phylogenetic identification and in situ detection of individual microbial cells without cultivation. Microbiol Rev 1995; 59:143-149.

AttwoodGT,ReillyK.Identification ofproteolytic rumen bacteria isolated from New Zealand cattle. J Appl Bacteriol 1995; 79(1):22-29. doi:10.1111/j.1365-2672.1995.tb03119.x Attwood GT, Reilly K, Patel BK. Clostridium proteoclasticum sp. nov., a novel proteolytic bacterium from the bovine rumen. Int J Syst Bacteriol 1996; 46(3):753-758. doi:10.1099/00207713-46-3-753

Briesacher SL, May T, Grigsby KN, Kerley MS, Anthony RV, Paterson JA. Use of DNA probes to monitor nutritional effects on ruminal prokaryotes and Fibrobacter succinogenes S85. J Anim Sci 1992; 70(1):289-295. doi:10.2527/1992.701289x

Bryant MP, Small N. The anaerobic monotrichous butyric acid-producing curved rod-shaped bacteria of the rumen. J Bacteriol 1956; 72(1):16-21.

Carvalho IPC, Fiorentini G, Castagnino PS, Jesus RB, Messana JD, Granja-Salcedo YT, Detman E, Padmanabha J, McSweeney CS, Berchielli TT. Supplementation with lipid sources alters the ruminal fermentation and duodenal flow of fatty acids in grazing Nellore steers. Anim Feed Sci Technol 2017; 227:142-153. doi:10.1016/j.anifeedsci.2017.02.017

Chao A. Estimating the population size for capture-recapture data with unequal catchability. Biometrics 1987; 43(4):783-791. 
Cirne DG, Delgado OD, Marichamy S, Mattiasson B. Clostridium lundense sp. nov., a novel anaerobic lipolytic bacterium isolated from bovine rumen. Int J Syst Evol Microbiol 2006; 56(Pt3):625-628. doi:10.1099/ijs.0.63730-0

Cole JR, Wang Q, Fish JA, Chai B, McGarrel DM, Sun Y, Brown CT, Porras-Alfaro A, Kuske CR, Tiedje JM. Ribosomal Database Project: data and tools for high throughput rRNA analysis. Nucleic Acids Res 2014; 42:633-642. doi:10.1093/nar/gkt1244

Coppi MV, Leang C, Sandler SJ, Lovley DR. Development of a Genetic System for Geobacter sulfurreducens. Appl Environ Microbiol 2001; 67(7):3180-3187. doi:10.1128/AEM.67.7.3180-3187.2001

Cotta MA. Interaction of ruminal bacteria in the production and utilization of maltooligosaccharides from starch. Appl Environ Microbiol 1992; 58(1):48-54.

Deng W,_Xi D, Mao H, Wanapat M. The use of molecular techniques based on ribosomal RNA and DNA for rumen microbial ecosystem studies: a review. Mol Biol Rep 2008; 35(2):26574. doi:10.1007\%2Fs11033-007-9079-1

Flint HJ, Scott KP, Duncan SH, Louis P, Forano E. Microbial degradation of complex carbohydrates in the gut. Gut Microbes 2012; 3(4):289-306. doi:10.4161/gmic.19897

Gillis M, Vandamme P, Vos PD, Swings J, Kersters K. Polyphasic taxonomy. In: Boone DR, Castenholz RW, Garrity GM, editors. The archaea and the deeply branching and phototrophic bacteria. New York: SpringerVerlag 2001:43-47.

Granja-Salcedo YT, Ramirez-Uscategui RA, Machado EG, Duarte Messana J, Takeshi Kishi L, Lino Dias AV, Berchielli TT. Studies on bacterial community composition are affected by the time and storage method of the rumen content. PLoS ONE 2017; 12(4): e0176701. doi:10.1371/journal.pone.0176701
Henderson G, Cox F, Ganesh S, Jonker A, Young W, Global Rumen Census Collaborators, Janssen P. Rumen microbial community composition varies with diet and host, but a core microbiome is found across a wide geographical range. Sci Rep 2015; 5: 14567. doi:10.1038/srep14567

Hill GM, Gates RN, Burton GW. Forage quality and grazing steer performance from Tifton 85 and Tifton 78 bermudagrass pastures. J Anim Sci 1993; 71(12):3219-3225. doi: $10.2527 / 1993.71123219 x$

Kim M, Morrison M, Yu Z. Status of the phylogenetic diversity census of ruminal microbiomes. FEMS Microbiol Ecol 2011; 76(1):49-63. doi:10.1111/j.1574-6941.2010.01029.x

Kobayashi Y, Shinkai T, Koike S. Ecological and physiological characterization shows that Fibrobacter succinogenes is important in rumen fiber digestion - review. Folia Microbiol (Praha). 2008; 53(3):195-200. doi:10.1007\%2Fs12223-008-0024-Z

Li RW, Wu S, Baldwin RLT, Li W, Li C. Perturbation dynamics of the rumen microbiota in response to exogenous butyrate. Plos One 2012; 7(1):e29392. doi:10.1371/journal.pone.0029392

Ling LY, Zhang Z, Wu M, Wu Y, Xun FJ. Isolation, screening, and identification of cellulolytic bacteria from natural reserves in the subtropical region of China and optimization of cellulase production by Paenibacillus terrae ME27-1. Biomed Res Int 2014;13. doi: $10.1155 / 2014 / 512497$

Lovley DR. Fe(III)- and Mn(IV)-reducing prokaryotes. In: Dworkin M, Falkow S, Rosenberg E, Schleifer K-H, Stackebrandt E, editors. The prokaryotes, in press. New York: Springer-Verlag, Inc.; 2000.

MAPA-Ministério da Agricultura, Pecuária e Abastecimento, 2016; [access date: Jan 2016] URL:http://www.agricultura.gov.br/animal/ especies/bovinos-e-bubalinos/. 
Magurran AE. Measuring biological diversity. Oxford, UK: Blackwell Publishing; 2004.

McAllister TA, Cheng KJ, Rode LM, Forsberg $\mathrm{CW}$. Digestion of barley, maize, and wheat by selected species of ruminal bacteria. Appl Environ Microbiol 1990;56(10):3146-3153.

McCann JC, Wiley LM, Forbes TB, Rouquette Jr FM, Tedeschi LO. Relationship between the Rumen Microbiome and Residual Feed Intake-Efficiency of Brahman Bulls Stocked on Bermudagrass Pastures. Plos One 2014; 9:3 e91864. doi:10.1371/journal.pone.0091864

Murray RGE. Bacterial diversity. In: Atlas RM, editors. Principles of Microbiology. New York: Mc Graw-Hill; 1997:1056-1097.

Neto AJ, Messana JD, Granja-Salcedo YT, Castagnino PS, Fiorentini G, Reis RA, Berchielli TT. Effect of starch level in supplement with or without oil source on diet and apparent digestibility, rumen fermentation and microbial population of Nellore steers grazing tropical grass. Liv Sci 2017; 202:171-179. doi:10.1016/j.livsci.2017.06.007

Oliveira MN, Jewell KA, Freitas FS, Benjamin LA, Toâtola MR, Borges AC, Moraes CA, Suen G. Characterizing the microbiota across the gastrointestinal tract of a Brazilian Nelore steer. Vet Microbiol 2013; 28(3-4):307-314. doi:10.1016/j.vetmic.2013.02.013

Pandya PR, Singh KM, Parnerkar S, Tripathi AK, Mehta HH, Rank DN, Kothari RK, CG Joshi. Bacterial diversity in the rumen of Indian Surti buffalo (Bubalus bubalis), assessed by $16 \mathrm{~S}$ rDNA analysis. J Appl Genet 2010; 51(3):395402. doi:10.1007/2FBF03208869

Pittman KA, MP Bryant. Peptides and Other Nitrogen Sources for Growth of Bacteroides Ruminicola. J Bacteriol 1964; 88:401-410.

Pruesse E, Quast C, Knittel K, Fuchs BM, Ludwig W, Peplies J, Glockner FO. SILVA: a comprehensive online resource for quality checked and aligned ribosomal
RNA sequence data compatible with ARB. Nucleic Acids Res 2007; 35(21):7188-7196. doi:10.1093/nar/gkm864

Reis RA, Ruggieri AC, Casagrande DR, Pascoa AG. Suplementação como estratégia do manejo das pastagens. Brazilian journal of animal science 2009; 38 Suppl: 147-159. doi/10.1590/S1516-35982009001300016

Russell JB. Fermentation of peptides by Bacteroides ruminicola B14. Appl Environ Microbiol 1983; 45:1566-1574.

San Vito E, Messana JD, Castagnino PS, Granja-Salcedo YT, Dallantoina EE, Berchielli TT. Effect of crude glycerin in supplement on the intake, rumen fermentation, and microbial profile of Nellore steers grazing tropical grass. Liv Sci 2016; 192:17-24. doi:10.1016/j.livsci.2016.08.011

Schmieder R, Edwards R. Quality control and preprocessing of metagenomic datasets. Bioinformatics 2011; 27(6):863+864. doi:10.1093/bioinformatics/btr026

Sijpestejin AK. Cellulose-decomposing bacteria from the rumen of cattle. Antonie Van Leeuwenhoek 1949; 15(1949):49-52.

Stanton TB, Canale-Parola E. Treponema bryantii sp. nov., a rumen spirochete that interacts with cellulolytic bacteria. Archives of Microbiology 1980; 127(2):145-156.

Sylvester JT, Karnati SK, Yu Z, Morrison M, Firkins JL. Development of an assay to quantify rumen ciliate protozoal biomass in cows using real-time PCR. Nutr J 2004; 134(12):33783384. doi:10.1093/jn/134.12.3378

Tajima K, Aminov RI, Nagamine T, Ogata K, Nakamura M, Matsui H, Benno Y. Rumen bacterial diversity as determined by sequence analysis of $16 \mathrm{~S}$ rDNA libraries. FEMS Microbiol Ecol 1999; 29(2):159-169. doi:10.1016/S0168-6496(99)00008-2 
Van Gylswyk NO. Enumeration and presumptive identification of some functional groups of bacteria in the rumen of dairy cows fed grass silage-based diets. FEMS Microbiol Lett 1990; 73:243-253.

Vandamme P, Pot B, Gillis M, Vos PD, Kersters $\mathrm{K}$, Swings J. Polyphasic taxonomy, a consensus approach to bacterial systematic. Microbiol Rev 1996; 60:407-438.

Wallace RJ, McKain N, Broderick GA. Breakdown of different peptides by Prevotella (Bacteroides) ruminicola and mixed microorganisms from the sheep rumen. Curr Microbiol 1993; 26(6):333-336.
Wu S, Ransom L, Baldwin RL, Li W, Li CE, Connor E, Li RW. The bacterial community composition of the bovine rumen detected using pyrosequencing of $16 \mathrm{~S}$ rRNA genes. Metagenomics 2012; 1(11):1-11. doi:10.1128/AEM.00720-15

Yang WZ, Beauchemin KA. Physically effective fiber: method of determination and effects on chewing, ruminal acidosis, and digestion by dairy cows. J Dairy Sci 2006; 89(7):2618-2633. doi:10.3168/jds.S0022-0302(06)72339-6

Young JP, Downer HL, Eardly BD. Phylogeny of the phototrophic rhizobium strain BTAi1 by polymerase chain reaction-based sequencing of a 16S rRNA gene segment. J Bacteriol 1991; 173(7):2271-2277. 